\title{
Ф.М. Достоевский \\ и газета А.С. Суворина «Новое время»
}

(статистический анализ)

Анастасия Прощенко

В статья представлены результаты впервые проведенного статистического исследования материалов газеты А.С. Суворина «Новое время» о жизни и творчестве Ф.М. Достоевского. Обозначен состав авторов издания, писавших о Достоевском, а также предпринята попытка выявить способы характеристики писателя на протяжении более чем 40 лет существования газеты. В тексте представлен обобщенный анализ массива новых данных, призванный показать необходимость дальнейших исследований в указанной области ${ }^{1}$.

Ключевые слова: Ф.М. Достоевский, А.С. Суворин, газета «Новое время».
(C) Прощенко Анастасия Андреевна преподаватель факультета журналистики МГУ имени М.В. Ломоносова (г. Москва, Россия), а9851825663@gmail.com
Данная статья является частью большого исследования, посвященного изучению образа Ф.М. Достоевского на страницах газеты А.С. Суворина «Новое время». Отношение периодической печати (газет) конца XIX - начала XX вв. к Ф.М. Достоевскому и его присутствие на страницах российской дореволюционной прессы, на наш взгляд, требуют дальнейших научных изысканий. Во многом именно газеты, распространившиеся в России в конце позапрошлого столетия и имевшие столь колоссальное влияние на общественное сознание (этот период нередко характеризуется как «золотой век русских газет»), формировали представления и отношение социума к тем или иным его представителям. Ф.М. Достоевский, уже в то время являясь одной из важнейших фигур в истории русской литературы, культуры и журналистики, бесспорно, привлекал к себе особое внимание общественности, а следовательно, и периодической печати. Будучи не только писателем, но также редактором, издателем и публицистом, Ф.М. Достоевский воспринимался коллегами-журналистами по-разному: в зависимости от политической направленности газеты, ее социальной функции, а нередко и от личного отношения ее сотрудников и владельцев. В связи с этим особенно важно 
понимать, чем обусловлены тон и характер различных газетных публикаций о Достоевском, каким образом контекст упоминаний о писателе способствует достижению социальных и политических целей издания. Однако серьезные обобщения в этой области невозможны без тщательного эмпирического исследования, необходимость которого мы и объясняем в данной статье.

\section{Ф.М. Достоевский и «Новое время»: к вопросу об изученности темы}

Отношение к Достоевскому российской дореволюционной прессы - тема весьма обширная, а потому мы приняли решение начать исследование с газеты А.С. Суворина «Новое время». И вот почему. Согласно определению «Энциклопедического словаря Брокгауза и Ефрона», к началу XX в. «Новое Время» - «наиболее распространенная (около 85 тыс. экз.) из больших политических русских газет <...> направление газеты может быть определено как националистически-консервативное»². Конечно, речь здесь пойдет не о национализме и консерватизме самого Достоевского - исследование политических взглядов писателя остается за рамками нашего исследования, так как не являются его непосредственным предметом. Однако нам интересно, как формировалось отношение к Достоевскому столь крупного и яркого в социальном и политическом смысле издания. Образ писателя, создаваемый на страницах "Нового времени», с одной стороны, мог отвечать интересам весьма значительного общественного среза (десятков тысяч читателей газеты), а с другой - наоборот, способствовать формированию этих интересов и мнений.

Издатель «Нового времени» А.С. Суворин, названный В.В. Розановым «Ломоносовым русской ежедневной печати», сыграл немалую роль не только в истории русской журналистики и литературы, но и в судьбе Ф.М. Достоевского (Прощенко, 2019), при- нял деятельное участие в увековечивании памяти писателя.

Ни одна другая газета конца XIX - начала XX вв. не писала о Достоевском так много, как «Новое время». С момента выкупа газеты Сувориным в 1876 г. по 1917 г. (год окончательного прекращения работы редакции) имя Достоевского было упомянуто в 618 публикациях, не считая рекламных материалов полного собрания сочинений и других книг автора. В процентном соотношении номера газеты, содержащие упоминания имени Ф.М. Достоевского, составляют 4\% от общего количества выпусков (последний - от 26 октября 1917 г. числится под номером 14 907) за 40 с небольшим лет.

Может показаться, что это небольшая цифра, однако это мнение ошибочно. Согласно «Указателю произведений Ф.М. Достоевского и литературы о нем на русском языке 1844-2004 гг.» (Белов, 2011), наиболее крупными газетами Российской империи периода 1860-1917 гг., писавшими о Достоевском, были «Голос», «Санкт-Петербургские ведомости», «Московские ведомости», «Биржевые ведомости», «Русские ведомости», «Русское слово», «Петербургский листок», «Новости и биржевая газета», «Русский инвалид», «Русь», «Речь», «Петербургская газета» и др. ${ }^{3}$ Сопоставив путем несложных подсчетов количество упоминаний о Ф.М. Достоевском в этих газетах за выбранный период, мы сделали вывод: ни одна другая газета Российской империи не уделяла личности и творчеству Ф.М. Достоевского больше внимания, чем «Новое время» Суворина (см. табл. 1).

Публикации «Нового времени» о Ф.М.Достоевском мало изучены. В настоящий момент в научный оборот введена лишь пятая часть существующих текстов. Таким образом, благодаря нашему исследованию может быть опубликован новый материал, который может значительно обогатить наши 
Таблица 1. Количество упоминаний о Ф.М. Достоевском в крупнейших российских газетах конца XIX - начала XX вв. ${ }^{4}$

\begin{tabular}{|l|c|c|}
\hline \multicolumn{1}{|c|}{ Газета } & Годы издания & $\begin{array}{c}\text { Кол-во упоминаний } \\
\text { о Ф. М. Достоевском }\end{array}$ \\
\hline Новое время & $1868-1917$ & 626 \\
\hline $\begin{array}{l}\text { Санкт-Петербургские } \\
\text { ведомости }\end{array}$ & $1728-1914$ & 143 \\
\hline Биржевые ведомости & $1880-1917$ & 98 \\
\hline Петербургская газета & $1867-1914$ & 77 \\
\hline Московские ведомости & $1756-1917$ & 71 \\
\hline Русские ведомости & $1863-1918$ & 53 \\
\hline Петербургский листок & $1864-1914$ & 50 \\
\hline Русь & $1903-1908$ & 38 \\
\hline Русское слово & $1895-1917$ & 31 \\
\hline Речь & $1906-1917$ & 24 \\
\hline Голос & $1863-1884$ & 23 \\
\hline Новости и Биржевая газета & $1880-1906$ & 18 \\
\hline
\end{tabular}

представления как о самом писателе, так и об известнейшем издании А.С. Суворина.

О газете «Новое время» и ее социальном, политическом и историческом значении написано немало работ (Соловьева, Шитова, 1977; Динерштейн, 1995 (а, б); Остапенко, 2002 (a, б); Малышев, 2004; Махонина, 2001, 2008, 2013; Патрикеева, 2013 $(a, 6)$ и др.). Полная историческая картина деятельности «Нового времени» была дана писателем Б.Б. Глинским в 1912 и 1916 гг.

Множество работ посвящено и неординарной личности издателя газеты А.С. Суворина: подробно изучены его дневниковые записи и переписка с русскими писателями ${ }^{6}$, а также его воспоминания о Достоевском (Волгин, 2016, 2018; Захаров, 1978, 1985; Прощенко, 2019 и др.). Однако собственно характер взаимоотношений Достоевского с газетой «Новое время», а также ее место в формировании и сохранении национальной памяти о нем до нынешнего времени не привлекали внимания исследователей. Между тем «Новое время» - газета, которую, по выражению самого Достоевского, он очень любил - играет немалую роль в судьбе писателя. Так, именно Суворин в «Новом времени» помогает установить справедливость в известной истории «с каймой ${ }^{7}$, а в 1881 г. раньше всех публикует сообщения о болезни и смерти Достоевского. Именно с подачи Суворина и с помощью его газеты был открыт сбор средств на памятник Достоевскому и открытие школы его имени в Старой Руссе. В «Новом времени» публиковались подробные отчеты об этих сборах, о подготовке материалов для полного собрания сочинений Достоевского, о литературных и музыкальных вечерах в поддержку школы, а также различные рекламные материалы о подписке на произведения покойного писателя.

\section{Тематика материалов газеты «Новое время» о Ф.М. Достоевском}

Разумеется, не все 618 публикаций «Нового времени» являются полноценными материалами о Достоевском: большая часть из них - это ссылки на те или иные высказывания или мнения писателя, однако 
не менее сотни из них - это самостоятельные тексты, посвященные критическому разбору произведений Достоевского, его биографии или личности (соотношение самостоятельных текстов к упоминаниям приблизительно 1:2). В число остальных материалов входят публикации 12 писем классика и 40 воспоминаний о нем разных лиц. Чаще всего тексты с упоминанием писателя встречаются в рубриках «Среди газет и журналов» (66), «Хроника» (65), «Литературные (критические) очерки» (52), «Объявления и сообщения» (15 текстов +25 отчетов о пожертвованиях на памятник и школу, о литературных вечерах в честь Достоевского и т.п.), «Театр и музыка» (30 текстов), «Письма в редакцию» (21), «Маленькая хроника» (20) и «Маленький фельетон» (19). Многие материалы не относятся ни к одной из рубрик и печатаются без заголовков. Интересно и то, что около половины всего контента газеты, касающегося Достоевского, выходит не только без заголовков, но и без подписей авторов (313 материалов, подписанных реальными именами или псевдонимами, и 298 неподписанных). Основные темы публикаций приведены в табл. $2^{8}$.

\section{Основные авторы, писавшие о Ф. М. Достоевском}

Авторами газеты «Новое время» о Достоевском было написано 313 материалов (см. рис. 1). Больше всего текстов принадлежат В. Буренину (60), В. Розанову (23) и А.С. Суворину (19).

В.П. Буренин работал критиком-обозревателем «Нового времени» с 1876 г. до закрытия газеты в 1917 г., поэтому именно его перу принадлежит большинство подписанных и множество неподписанных текстов газеты. Об отношениях (литературных и личных) написано мало работ (Баршт, 2017, 2018). В указанных исследованиях затронут в основном ранний период творчества Буренина, большинство текстов «Нового времени» до сих пор остаются неизученными.

Наиболее близкое к нашей теме исследование было проведено Н.Ю. Казаковой «В.В. Розанов и газета А.С. Суворина “Новое время"» (2000). В данной работе подробно изучены приемы и методы газетной деятельности В.В. Розанова на примере его литературно-критических статей о русской литературе в газете «Новое время». По нашим подсчетам, перу В.В. Розанова принадлежит не менее 23 материалов, опубликованных в издании Суворина и упоминающих Ф.М. Достоевского (о влиянии творчества Достоевского на Розанова подробно рассказано в работе И.Л. Волгина «Достоевский и Розанов: школа жанровых имитаций» (2007)).

По признанию самого Суворина, в «Новом времени» вышло множество его статей без подписи. Кроме того, известно, что именно А.С. Суворин вел в газете рубрику о театре, в которой имя Ф.М. Достоевского упоминается, как минимум, в 30 текстах. К статьям Суворина о Достоевском обращались многие исследователи.

Разумеется, оценки личности и творчества Достоевского у каждого из вышеперечисленных авторов различны: «Новое время», при всей своей консервативности, транслировало зачастую совершенно различные мнения. Со многими авторами «Нового времени» Достоевский был знаком лично, другие оказывались детьми его друзей и знакомых. С некоторыми (как, например, с В.В. Розановым) писатель знаком не был, однако его наследие сегодня немыслимо без критических очерков автора «Опавших листьев». И вопрос взаимоотношений Достоевского с авторами «Нового времени» заслуживает отдельного исследования.

\section{Изменение частоты упоминаний о Достоевском в различные годы}

Нам показалось целесообразным в первую очередь сказать несколько слов 
Таблица 2. Основная тематика материалов газеты «Новое время» о Ф.М. Достоевском

\begin{tabular}{|c|c|}
\hline Тема & Примеры текстов \\
\hline $\begin{array}{l}\text { Сравнение Ф.М. Достоевского } \\
\text { с И.С. Тургеневым }\end{array}$ & 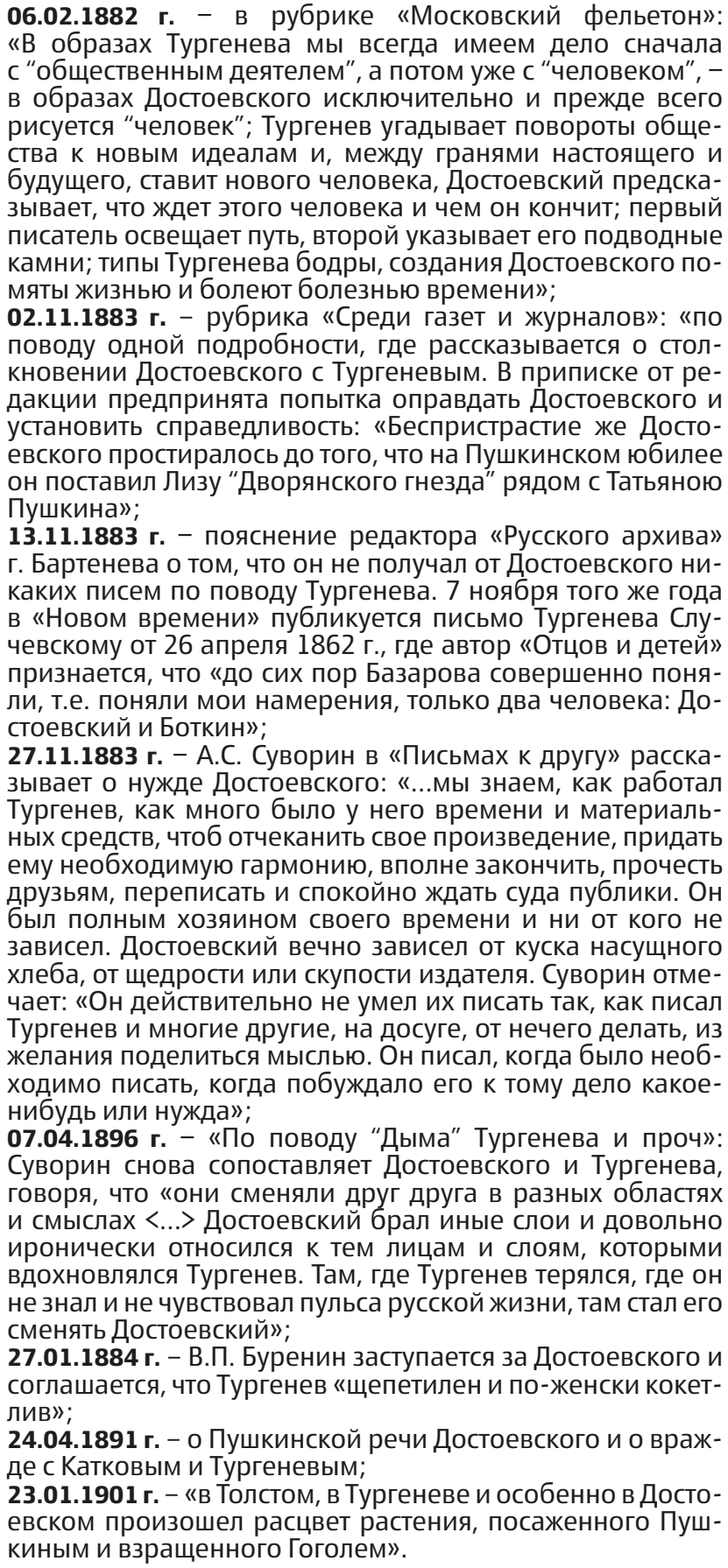 \\
\hline
\end{tabular}


Сравнение Ф.М. Достоевского с Л.Н. Толстым

10.01.1891 г. в «Библиографических новостях» сообщается о смерти сербского писателя Лазо Лазаревича, который писал: «Разве можно писать что-нибудь после Толстого и Достоевского? Я чувствую себя совершенно раздавленным этими гигантами»;

12.12.1893 г.- «Среди газет и журналов» - ответ на статью А.Л. Флексера (напечатанную под псевдонимом Г. Homo), в которой он осуждает "эпилептические идеи Достоевского» и «философское похотничество Толстого»;

12.04.1896 г. - о Толстом, о его высказываниях о современных беллетристах, в том числе о Достоевском;

29.11.1896 г. - В.П. Буренин об очерке Р.И. Сементковского про Лескова, поставленного в один ряд с Достоевским и Толстым. Буренин не согласен: «Достоевского и особенно Толстого признали корифеями»;

10.01.1900 г. - интервью с Л.Н. Толстым, где он так отзывается о Достоевском: «По своей технике он ниже всякой критики, но он не только нам, русским, но и всей Европе открыл целый новый мир. Техника вовсе не главное, как теперь думают». На следующий день выходит статья В. Розанова «о Толстом», где он пишет, что Достоевскому удалась дважды «экзальтированная пассивность. В философии он был подвижен, гениален, отнюдь не монотонен, всего менее пассивен»;

11.12.1900 г. - перепечатка из «Русского вестника» о Толстом и Достоевском, их литературных отношениях;

03.11.1900 г. - «Несмотря на некоторые точки соприкосновения с Достоевским, граф Толстой совсем не мистик, а один из величайших реалистов в мировой литературе»; 30.11.1900 г. - «Насколько читают сегодня Толстого и Достоевского, показывают библиотечные отчеты, которые, сколько мне их ни приходилось видеть, обыкновенно называют этих писателей на первом месте по количеству требований»;

20.02.1901 г. - Д. Мережковский «Об отношении Льва Толстого и Достоевского к христианству», вторая часть статьи «Достоевский против Толстого»;

25.03.1901 г. - размышление о русской живописи: «Отсутствие художественного пошиба у Достоевского и Толстого не помешало им сделаться великими писателями».

Переводы произведений Достоевского на иностранные языки и восприятие его творчества за рубежом
10.01.1885 г. - о том, как началась на Западе известность Л.Н. Толстого и Ф.М. Достоевского. Немецкая критика о Гоголе и Достоевском;

25.02.1886 г. - о напечатанном в пражском журнале Zlata Praha критическом очерке о Достоевском и Тургеневе;

09.01.1891 r. - «Французы проявляют свою дружбу к России и к русскому <...> они даже виллы свои называют Dauchka, Liuba и Milachka <...> У светских барынь на самом видном месте Достоевский и Толстой»;

15.08.1891 г. - о французской литературе, которая «заимствовала у Достоевского элемент сострадания»;

19.09.1892 г. в рубрике «Хроника» - в одном из парижских отелей подают «салат Лев Толстой, Достоевский и Скобелев». Шуточная приписка от «Нового времени»: «Это уже не салат, а целый винегрет»;

09.04.1892 г. - о романе французского писателя Эдуарда Рода La sacrifiee, «по основному мотиву очень напоминающем "Преступление и наказание" Достоевского»; 
Таблица 2. Основная тематика материалов газеты «Новое время» о Ф.М. Достоевском (продолжение)

\begin{tabular}{|c|c|}
\hline & 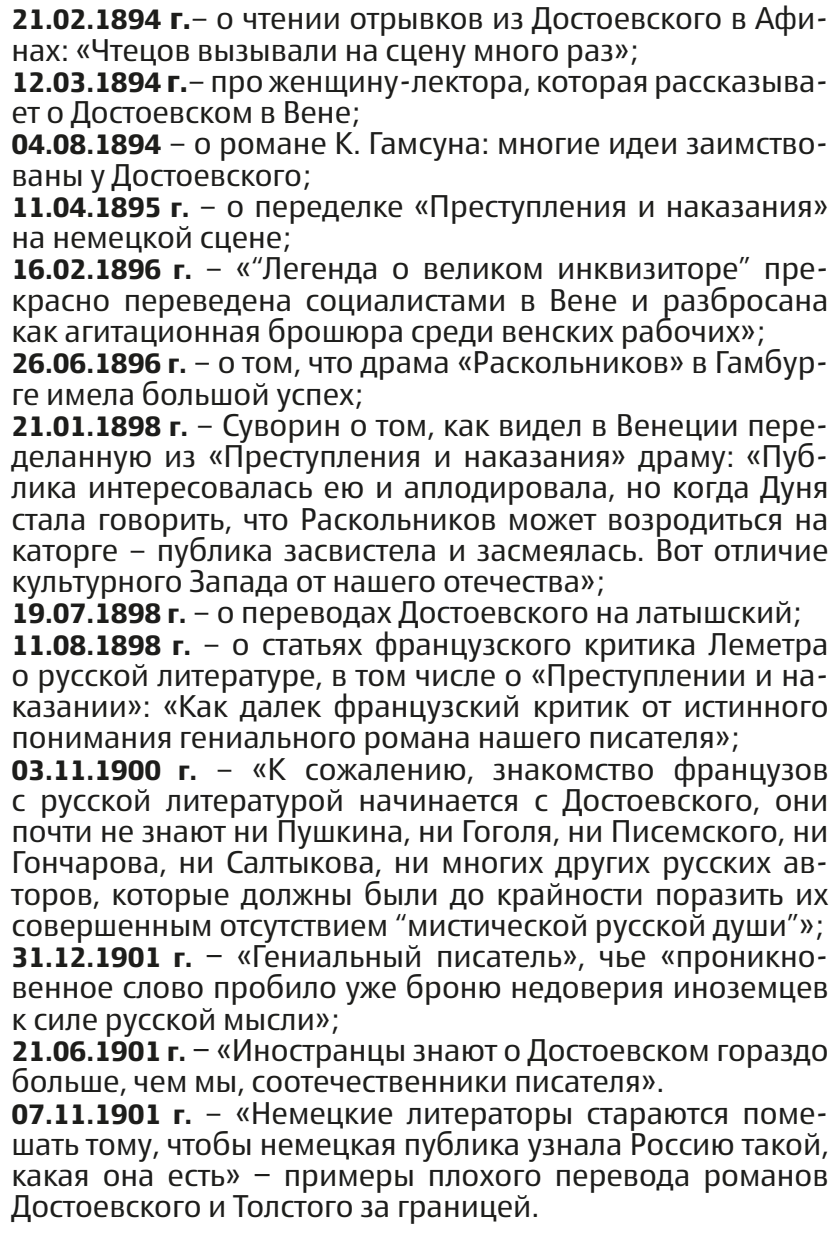 \\
\hline $\begin{array}{l}\text { Отношение Достоевского } \\
\text { к другим странам и народам }\end{array}$ & $\begin{array}{l}\text { 13.03.1882 г. - отчет о лекции О. Миллера, в которой лек- } \\
\text { тор объяснял, почему Достоевский «не любил заграницу»; } \\
\mathbf{1 1 . 1 0 . 1 8 8 3 ~ г . ~ - ~ к о р р е с п о н д е н ц и я ~ и з ~ Б о л г а р и и : ~ « К ~ с о ж а - ~} \\
\text { лению, скоро исполнились пророческие слова великого } \\
\text { писателя Достоевского, писавшего еще в } 1878 \text { году по по- } \\
\text { воду освобождения Болгарии, что пройдут времена и она } \\
\text { не будет благодарна России за свое освобождение, хотя } \\
\text { и найдутся люди, которые будут преданы России, но над } \\
\text { ними будут насмехаться и преследовать их. Жаль, что так } \\
\text { скоро исполнились пророческие предсказания»; } \\
\mathbf{1 9 . 1 0 . 1 8 9 3} г \text { г. - в отчете о банкете русской прессы в Париже } \\
\text { цитируется письмо Пастера со словами Достоевского про- } \\
\text { тив западной культуры и Парижа; } \\
\mathbf{0 4 . 0 7 . 1 8 9 4} \text { г. - Достоевский об Италии; } \\
\mathbf{2 1 . 0 2 . 1 9 0 1 ~ г . ~ - ~ о ~ к н и г е ~ Ч е р н я х о в а ~ п р о ~ е в р е е в , ~ в ~ н а ч а л е ~} \\
\text { приводится высказывание Достоевского; } \\
\mathbf{1 5 . 0 3 . 1 9 0 1 ~ г . ~ - ~ о б ~ о т н о ш е н и и ~ Д о с т о е в с к о г о ~ к ~ е в р е я м . ~}\end{array}$ \\
\hline
\end{tabular}


Таблица 2. Основная тематика материалов газеты «Новое время» о Ф.М. Достоевском (окончание)

Политические и религиозные воззрения Достоевского

Достоевский и театр

27.02.1882 г. - цитируется отрывок из письма Достоевского: «Все любят царя, я его обожаю";

31.10.1883 г. - «при сооружении памятника руководствовались строго православными идеями. Внизу текст из Евангелия, притча о сеятеле: "Аще же умрет, много плода сотворит" [эпиграф к «Братьям Карамазовым. - А.П.]»;

18.12.1896 г. - рассказ, где идеалом главного героя был Достоевский, «сам претерпевший подобный же нравственный, религиозный и политический переворот в своей бурно сложившейся жизни и вышедший из каторги воином против знамени, за которое стоял до каторги»;

26.03.1901 г. - о лекции Д.Н. Вергуна «Достоевский и славянСтво");

06.03.1901 г. - про «тело» христианства и идею почвы у Достоевского.

11.03.1894 r. - о драме «Преступление и наказание» в Турине;

26.06.1896 г. - «драма «Раскольников» в Гамбурге имела большой успех»;

01.01.1900 г. - о спектаклях 1899 г., об успехе переделки «Преступления и наказания» в Малом театре и «Идиота» в Александрийском;

17.11.1901 г. - об особой постановке «Преступления и наказания» на французском языке;

09.12.1901 г. - «наибольшим успехом пользовались переделки Достоевского и Крестовского»;

01.05.1900 г. - об актере П.Н. Орленеве и его гастролях по России со спектаклем «Преступление и наказание»;

09.11.1900 г. - об успехе Н. Северского в роли Раскольникова;

07.11.1900 г. - объявление о спектакле «Преступление и наказание» в театре Литературно-художественного общества;

о том небольшом отрезке существования издания, когда Ф.М. Достоевский еще был жив и выражал свое отношение к газете, ее статьям и авторам. Всего в «Новом времени» Суворина вышло 68 материалов с прижизненным упоминанием фамилии писателя (см. рис. 2). Автору статьи удалось найти восемь текстов за 1873 г. и один за 1875 г. Интересно, что три из них подписаны псевдонимом «А.С.», который некоторые исследователи (напр., Масанов, 19609; Белов, 2011: 70) относят к А.С. Суворину10. Характерно также, что отношение к личности и творчеству Достоевского в «Новом времени» начала 1870 гг. отличается от последующих оценок, данных после 1876 г. Так, в № 16 от 16 января 1873 г. (рубрика «Журналистика») была опубликована рецензия на роман «Бесы» (с подписью А.С.). В критическом отзыве произведение Достоевского названо «дикой, болезненной фантасмагорией высокого и когда-то светлого ума», а также сказано, что в романе «сквозит какое-то отчаянное сознание своего бессилия и вместе с тем слепая, неумолимая зависть <...> ко всему молодому, живому, свежему, сильному!» И как бы в довершение удара делается вывод: «После "Бесов" нам остается только поставить крест на этом писателе и считать его деятельность законченной».

С приходом А.С. Суворина оценки «Нового времени» по отношению к Достоевскому становятся всё мягче, и в конце концов 


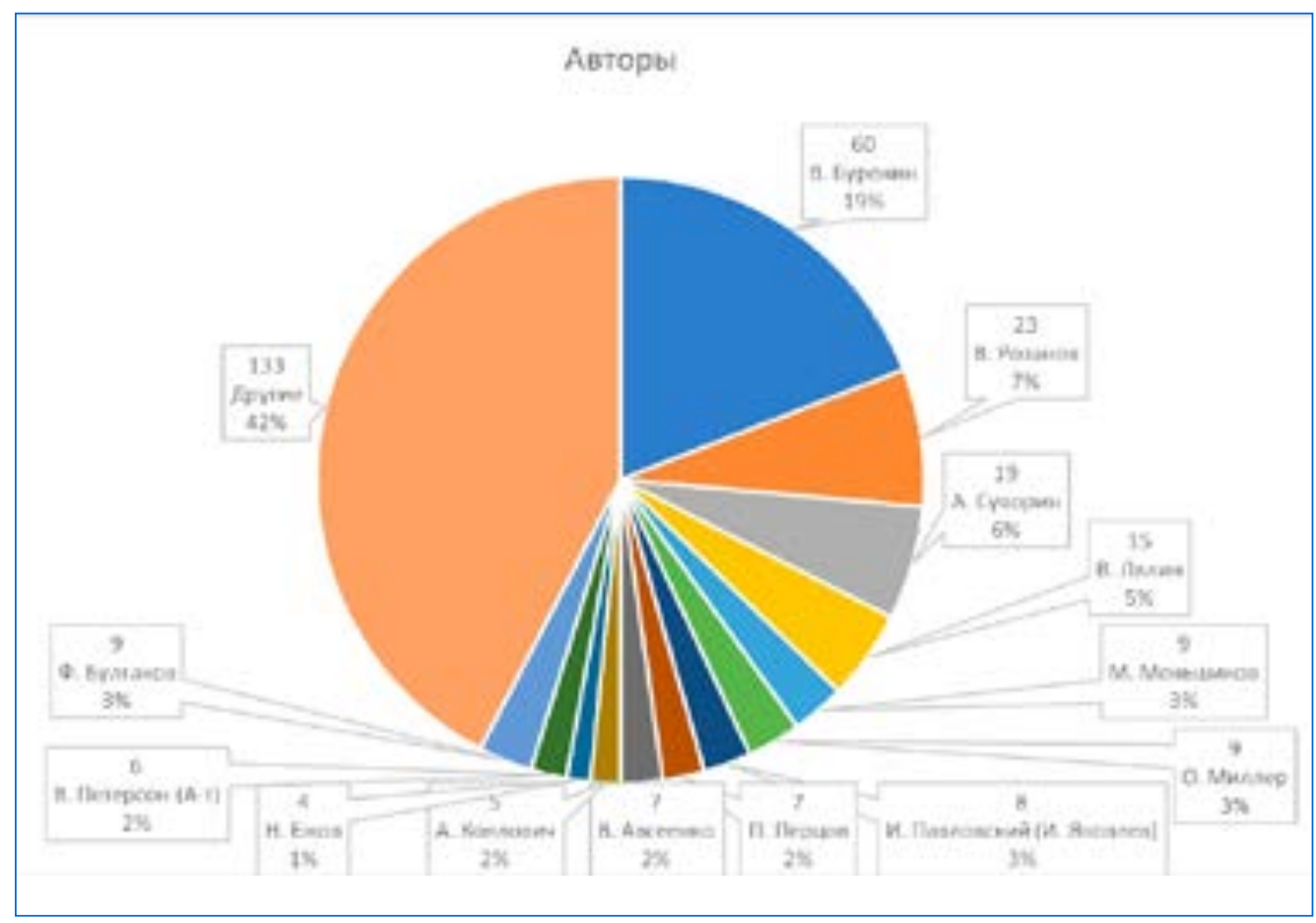

Рисунок 1. Авторы газеты «Новое время» писавшие о Ф.М. Достоевском в 1876-1917 гг.

автор «Великого Пятикнижия» признается «гением» и «провидцем».

Как видно из рисунка 2, с 1877 г. интерес «Нового времени» к личности и творчеству Ф.М. Достоевского стремительно шел вверх. Большинство текстов 1876-1879 гг. посвящены разбору выпусков «Дневника писателя»; возросшие в 1880 г. показатели связаны с «эпизодом с каймой» (8текстов из 31) в начале года и ошеломляющим успехом Пушкинской речи (10 из 31) в середине года. До 28 января 1881 г. (даты смерти писателя) о Достоевском успели упомянуть лишь в четырех материалах. Посмертные упоминания отражены на рисунке 3.

Данный рисунок наглядно подтверждает слова А.С. Суворина, которые он записал в своем дневнике 28 сентября 1899 г., вспоминая о событиях почти двадцатилетней давности: «Публика бросилась читать и покупать Достоевского. Точно смерть его открыла, а до того его не было»11. Или, как писал Житель (А.Н. Дьяков) в «Новом времени» 12 января 1892 г., «его [Достоевского. А.П.] просто не знали, не читали в толпе <...>, а когда Достоевский умер, о нем стали шуметь в газетах и журналах и этот шум сразу сделал блестящий успех его сочинений»12. Никогда более о Достоевском не писали так много, как в год его смерти (отметим, что 1881 г. был ознаменован еще одним важнейшим для России трагическим происшествием - убийством императора Александра II). Количество ежегодных упоминаний о Достоевском после его смерти выросло по сравнению с количеством ежегодных прижизненных упоминаний (не говоря уже об изменении оценок личности и творчества писателя). Всплеск интереса газеты «Новое время» к Ф.М. Достоевскому заметен на рубеже XIX и XX столетий, что легко объясняется характерной для 


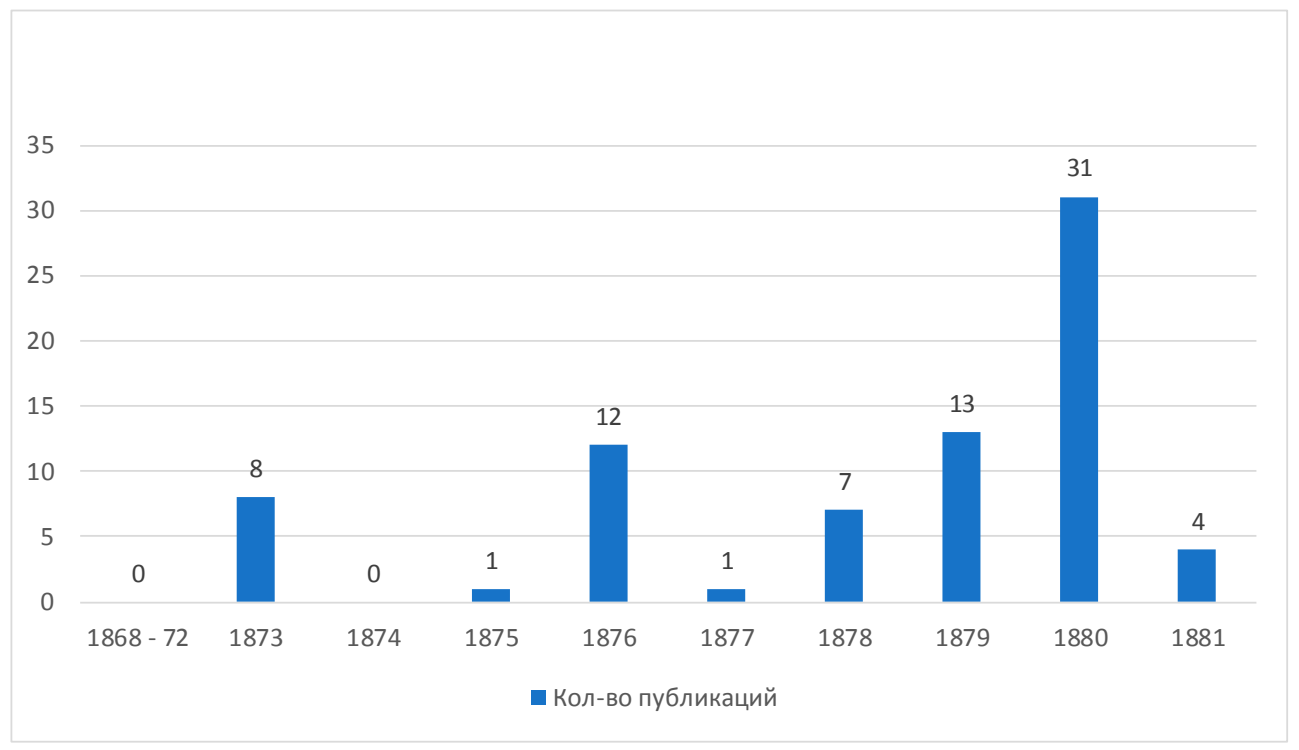

Рисунок 2. Распределение прижизненных упоминаний о Ф.М. Достоевском в газете «Новое время» по годам

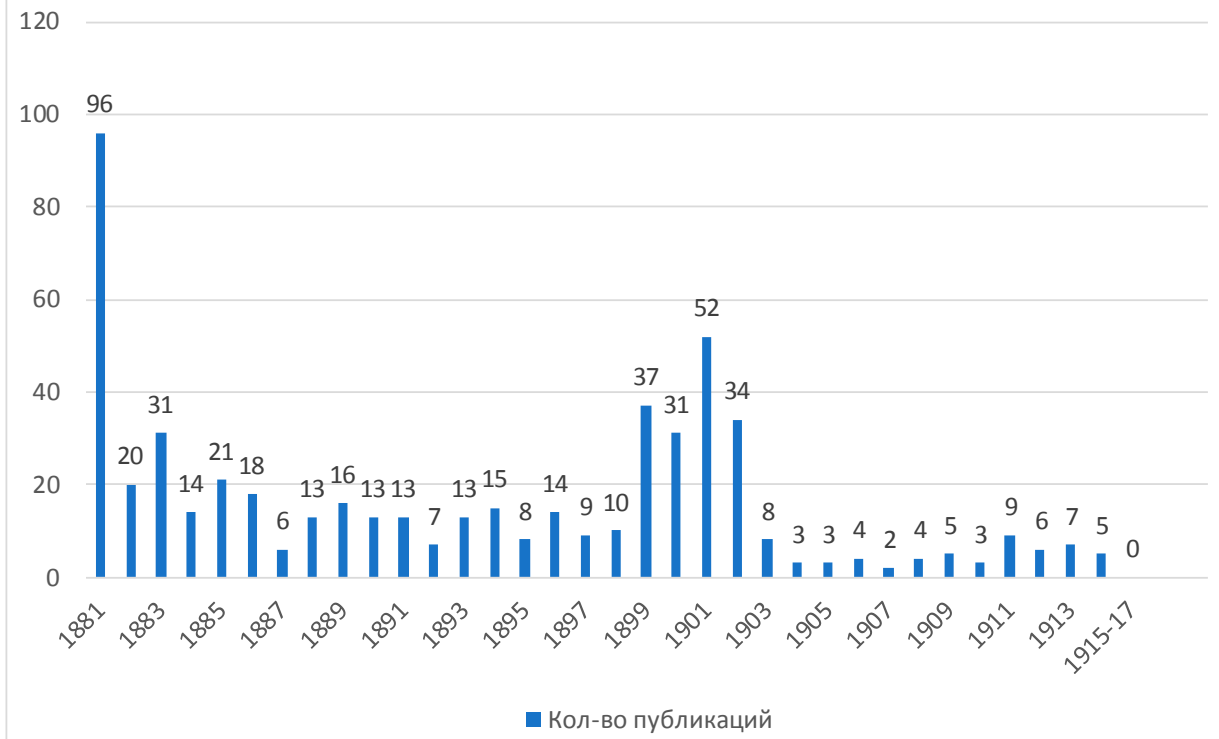

Рисунок 3. Распределение посмертных упоминаний о Ф.М. Достоевском в газете «Новое время» по годам 
СМИ тенденцией «подогревать» интерес публики в юбилейные годы: в 1901 г. отмечалось 80 лет со дня рождения и 20 лет со дня смерти писателя. Кроме того, данный всплеск можно объяснить тем, что в 1898 г. в «Новое время» приходит В.В. Розанов - его перу принадлежит не менее 23 текстов, так или иначе обращенных к писателю. Мистицизм, экзистенциальные поиски, свойственные русской литературе рубежа веков, также могут являться причиной особенно острого интереса к Достоевскому конца 1890-х - начала 1900-х гг.: именно в этот период автора «Бесов» и «Дневника писателя» чаще всего именуют пророком, провидцем, гением, вновь обращаются к его словам и идеям.

Тем не менее уже начиная с 1903 г. заметен резкий спад внимания «Нового времени» к личности Ф.М. Достоевского. На наш взгляд, это связано, с одной стороны, с напряженной политической обстановкой в стране, с другой - с ухудшением дел товарищества «Новое время» и лично А.С. Суворина, который в конце 1900 гг. фактически отошел от дел. Кроме того, этот спад интереса к Достоевскому может быть связан с появлением новой литературы, которую уже не удовлетворяет эстетика реализма: с началом века русскую общественную мысль все больше захватывает модернизм.

\section{Выводы}

Результаты нашей работы призваны стимулировать развитие новых историкожурналистских и литературоведческих исследований. Полученное в результате работы новое знание существенно обогащает наши представления о газете «Новое время» и ее роли в формировании образа Ф.М. Достоевского в общественном сознании. В данной статье предпринята попытка зафиксировать присутствие Ф.М. Достоевского в общественном сознании (в том числе в прессе) на примере материалов газеты «Новое время». Наше исследование доказывает, что ни одна другая газета не писала о Достоевском так много и часто, как «Новое время» А.С. Суворина, ни одна другая газета не сыграла в сохранении памяти о нем такой роли. Несмотря на то, что, по мнению многих исследователей и публицистов (в том числе самого Суворина), осознание истинного значения литературной деятельности Достоевского пришло к обществу только после смерти писателя, авторы «Нового времени» по преимуществу поддерживали его идеи и начинания, когда он был жив. На наш взгляд, дальнейшие разыскания в области означенной темы могут существенно дополнить историю русской литературы и журналистики.

\section{Примечания}

${ }^{1}$ Исследование выполнено при финансовой поддержке РФФИ в рамках научного проекта № 18-012-90021 «Достоевский: жизнь и наследие. Биографические лакуны. Рецепция творчества и судьбы в национальном сознании (1881-1921)».

2 Энциклопедический словарь Ф.А. Брокгауза и И.А. Ефрона (в 86 т. с илл. и доп. мат.). Режим доступа: http://www.vehi.net/brokgauz/index.html (дата обращения: 24.07.2019).

${ }^{3}$ Статистика осуществлялась с помощью указанной библиографии С.В. Белова: самостоятельно изучить все выпуски крупных российских газет за полувековой период физически невозможно. К тому же эта работа уже проделана командой исследователей под руководством С.В. Белова, пусть и с некоторыми погрешностями. 
${ }^{4}$ Для сравнений выбраны далеко не все серьезные русские газеты по той причине, что количество упоминаний о Достоевском в них ничтожно мало: например, в «Утре России» - одно, в газете «День»- восемь, в провинциальной прессе ситуация аналогична.

5 Цифры приведены по справочнику С.В. Белова и могут допускать небольшую погрешность.

6 Письма русских писателей к А.С. Суворину. Л.: Изд-во гос. публ. библ. им. М. Е. Салтыкова-Щедрина, 1927.

7 Впервые об этом эпизоде, не называя имени Ф.М. Достоевского, рассказал в 1855 г. И.И. Панаев в «Современнике». В 1880 г. П.В. Анненков в апрельском номере «Вестника Европы» сообщил, будто Ф.М. Достоевский был такого высокого мнения о своем таланте, что потребовал напечатать его первое произведение «Бедные люди» «с каймой по сторонам страниц». А.С. Суворин возразил Анненкову в «Новом времени» (от 4 апреля и 2 мая 1880 гг.), сообщив, что в «Петербургском сборнике» 1846 г. “Бедные люди» напечатаны без «каймы». Редакция «Вестника Европы» попыталась оправдаться, завязалась полемика, в результате которой Суворин защитил честь Достоевского (см., напр.: Волгин, 2018: 493, 641-644, 646).

8 Подробнее о каждой категории тем речь пойдет в других работах, опубликованных в рамках данного исследования.

${ }^{9}$ Масанов И.Ф. Словарь псевдонимов русских писателей, ученых и общественных деятелей: в 4 т. М.: Изд-во Всесоюз. кн. палата, 1960. Т. 4. С. 558.

10 Однако исследователь Л.Е. Азарина (2008) доказывает, что это мнение ошибочно, и мы с ней согласны.

${ }^{11}$ Дневник Суворина А.С. М.-Пг., 1923. С. 212 (запись от 28 сентября 1899 г.).

12 Житель. Талант, как честность // Новое время. 1892. № 5701. Янв., 12 (24).

\section{Библиография}

Азарина Л.Е. Литературная позиция А.С. Суворина: автореф. дис. ... канд. филол. наук. М., 2008.

Баршт К.А. Пародии В.П. Буренина в творческой истории романа Ф.М. Достоевского «Бесы» и в статье «Господин Щедрин, или раскол в нигилистах» // Нов. филол. вестн. 2018. № 2 (45). С. 73-83.

Баршт К.А. «Цинический реализм» В.П. Буренина как предтекст «реализма в высшем смысле» Ф. М. Достоевского» // Вопросы литературы. 2017. Ноябрь-декабрь. C. $165-190$.

Белов С.В. Указатель произведений Ф.М. Достоевского и литературы о нем на русском языке 1844-2004 гг. СПб: Рос. нац. библ., 2011.

Волгин И.Л. Достоевский и Розанов: школа жанровых имитаций // Studia Rossica. Vol. XIX. 2007. P. 97-111.

Волгин И.Л. Последний год Достоевского. 5-е изд. М.: АСТ, 2016.

Волгин И.Л. Родиться в России. Достоевский: начало начал. М.: Акад. проект, 2018.

Глинский Б.Б. Алексей Сергеевич Суворин (Биографический очерк) // Исторический вестник. 1912. № 9. С. 3-60. 
Глинский Б.Б. «Новое время» (1876-1916 гг.): Исторический очерк. Пг.: Тип. Т-ва А.С. Суворина «Новое время», 1916.

Динерштейн Е.А. (а) А.С. Суворин и его газета «Новое время» // Нов. лит. обозрение. 1995. № 15. С. 183-193.

Динерштейн Е.А. (б) Публицист «крайних убеждений». Путь А.С. Суворина к «Новому времени» // Биографический альманах «Лица». 1995. № 6. С. 238-274.

Захаров В.Н. По поводу одного мифа о Достоевском // Север. 1985. № 11. С. 113-120.

Захаров В.Н. Проблемы изучения Достоевского. Петрозаводск: Изд-во ПетрГУ, 1978.

Казакова Н.Ю. В.В. Розанов и газета А.С. Суворина «Новое время»: дис. ... канд. филол. наук. М., 2000

Малышев Д.В. Газета «Новое время» и периодическая печать Петрограда в 1917 году: дис. ... канд. ист. наук, СПб, 2004.

Махонина С.Я. А.П. Чехов и А.С. Суворин (Новые материалы к старой теме) // Вестн. Моск. ун-та. Сер. 10: Журналистика. 2008. № 6. С. 149-160.

Махонина С.Я. А.С. Суворин и «князья-журналисты» // Русская литература и журналистика в движении времени. Ежегодник 2012 / под ред. Г.С. Лапшиной, Е.И. Орловой. М.: Фак. журн. МГУ, 2013. С. 112-124.

Махонина С.Я. А.С. Суворин портрет на фоне новых книг о нем // Вестн. Моск. унта. Сер. 10: Журналистика. 2001. № 2. С. 108-126.

Остапенко Л.А. (а) Газета А.С. Суворина «Новое время» в общественно-политической жизни России 1907-1912 гг.: автореф. дис. ... канд. ист. наук. Н. Новгород, 2002.

Остапенко Л. А. (б) Реформы П.А. Столыпина в оценках газеты «Новое время». Н. Новгород: Нижегородск. гуманит. центр, 2002.

Патрикеева О.А. (б) Газета «Новое время»: вклад в развитие парламентской журналистики в России (начало XX в.) // Локус: люди, общество, культуры, смыслы. 2013. Вып. 2. С. 5-13.

Патрикеева О.А. (а) Газета «Новое Время» о проблеме революционного террора в России (1905-1907 гг.) // Вестн. Ленинградск. гос. ун-та им. А.С. Пушкина, 2013. № 1. C. 15-23.

Прощенко А.А. «Достоевец» Суворин: от противоборства к сближению // Неизвестный Достоевский. 2019. № 2. C 149-170. DOI: 10.15393/j10.art.2019.4061

Соловьева И., Шитова В. А.С. Суворин. Портрет на фоне газеты // Вопросы литературы. 1977. № 2. С. 162-189. 